\title{
Manager's Effort and Endogenous Economic Discrimination
}

\author{
Jaime Orrillo \\ Paulo R. A. Loureiro
}

\author{
Universidade Católica de Brasília \\ Universidade Católica de Brasília
}

\section{RESUMO}

Vamos assumir que a oferta de trabalho consiste de dois tipos de trabalhadores, I e 2. Ambos os trabalhadores são igualmente produtivos e exibem funções de oferta com a mesma elasticidade. Consideramos uma firma (empresário ou acionistas), a qual é competitiva no mercado de produtos e monopsonista nos mercados de insumos. A firma usa os serviços de um gerente quem tem um alto capital humano e cujo salário é dado pelo mercado. Suponhamos que o gerente não gosta de trabalhar com um tipo de trabalhador, digamos o tipo I. Se permitirmos que o esforço do gerente seja um insumo adicional sem nenhum custo extra (além de seu salário), a decisão de salários será diferente para ambos os trabalhadores. Isto é, haverá um diferencial de salários e, em conseqüência, uma discriminação econômical endógena nos mercados de trabalho.

\section{PALAVRAS-CHAVE}

esforço gerencial, diferencial de salários, discriminação econômica

ABSTRACT

Assume a labor supply consisting of two types of workers, I and 2. Both workers are equally productive and exhibit supply functions with the same elasticity. We consider a firm (entrepreneur or shareholders) that is competitive in the output market and monopsonistic in input markets. The firm uses the services of a manager who has a high human capital and whose wage is given by the market. It is supposed that the manager does not like to work with one type of worker, say type I. If we allow the manager's effort to be an additional input without any extra (in addition to his salary) cost for the firm, then the firm's pricing decision will be different for both workers. That is, there will be a wage differential and therefore endogenous economic discrimination ${ }^{2}$ in the labor markets.

KEY WORDS manager's effort, wage differential, economic discrimination

JEL Classification

$J 7 I, J 4 I, J 42$

1 Ver BLACK (1995) para uma definição de discriminação econômica.

2 See BLACK (1995) for a definition of economic discrimination. 


\section{INTRODUCTION}

The production, and consequently the profit, of the firm may be affected by the relationship among its workers. This relationship may be positive, in the sense that it may stimulate an increase in the production without any additional cost for the firm. The productivity of a worker may increase if his workmate exhibits a behavior that motivates him. This behavior would not be economic, but would rather be related to education, good humor, or ethnic characteristics, etc.

However, the opposite may occur. That is, the production level may be affected in a negative way (tendency to fall) because of the bad relationship among workers. For instance, the simple fact of being envious of someone (see FARIA, 1998) or not liking to work with a certain employee may be an incentive that negatively affects the productivity of some workers, and therefore the production level of the firm. There are several situations in which this bad relationship may arise and, at the same time, there are many solutions. To quote just a few: one worker that creates ${ }^{3}$ conflict among other workers could simply be dismissed or moved to another place where the firm operates. However, when the employee is a manager (or a high-standing employee) whose human capital is high, the problem is not so easy to solve. The supply of this kind of employee is scarce and to fire him could bring bad consequences for the firm.

As the only aim of the firm is to maximize profits, they (entrepreneur or householders) will have several alternatives to handle this situation without incurring additional costs. In these cases, there should be some kind of bargaining between the firm and the manager: from an economic point of view, it would be better if the firm maintained such a manager, ${ }^{4}$ provided he does not require extra salary from the firm, than to hire more workers who annoy him. On the other hand, for each worker ${ }^{5}$ not hired, the manager must increase his own effort in order to maintain the production level. That is, the cost must be only of the manager and not of the firm (entrepreneurs

3 The worker may have a characteristic that annoys his workmates.

4 Although he may not like some workers that the firm might hire.

5 Discriminated by the manager. 
or shareholders). From this point on, we shall refer to such a manager as discriminating manager.

The purpose of this paper is to attempt to solve the firm's problem in the presence of a discriminating manager. Since the problem is in the labor market, we assume the firm is monopsonistic in this market, and not in the markets of managers, and competitive in the output markets. Therefore, a solution for the firm would be to allow the manager to have a kind of power of decision that affects the hiring decisions (of the firm). The cost of this power of decision would be his effort. To be more precise, the manager would have to increase his effort and not demand any extra salary (which will in turn increase the level of production) to avoid the necessity of hiring more workers that annoy the discriminating manager. Thus there is a tradeoff that the manager has to face: to increase his effort and to have to put up with employees who annoy him.

The results of this paper show that the trade-off faced by the discriminator manager brings a wage differential as a consequence, which in turn causes economic discrimination (from entrepreneurs or shareholders) in the labor markets. Thus discrimination emerges in an endogenous way.

To place our paper in the context of the existing literature, it is useful to mention that this paper is closer to the pioneering works of Becker (1971) and Arrow (1973), than to that of Phelps (1972). The work of Phelps is more concerned with statistical discrimination, which is an important subject but does not concern us here. Our work is closer to the employer discrimination model of Becker (1971). In Becker's work the firm maximizes profits without taking into account any employee's effort, but considers the coefficient of discrimination due to a taste for discrimination. However, our model incorporates the manager's effort as an additional input without incurring any cost. We wish to clarify that almost all of the theoretical works have been developed within a competitive setting. Ours is quite different since the firm in our model acts competitively in the output market and as a monopsony in the labor markets. 
The reason we consider a monopsony is for the sake of simplicity since the only thing that we want to analyze is that the firm has a certain market power. A similar work - concerning to the degree of monopsonistic power was analyzed by Black (1995) in the context of labor market search model.

Despite this power, the decision of the base salary depends on the elasticity of the supply of labor. If the monopsonistic firm faces labor supplies sharing the same elasticity, there will be no economic discrimination. However, if there is a discriminating manager, economic discrimination on the part of the monopsonistic firm will appear. We must stress that our discrimination is due to friction among workers. Among the authors of works concerning this kind of discrimination Frijters (1997) stands out.

It would be useful to point out the fundamental difference between the efficiency wage model of Solow (1979) and ours. While in the latter the firms pay above market-clear wages in order to motivate workers to raise their effort, in our model the firm stops hiring workers of type A to stimulate the manager to increase his effort. For another way of incorporating the manager's behavior in the firm's ${ }^{6}$ decisions, see Faria (2000).

It would be useful to mention authors who explain the reason for wage differentials. Among the most important we find Shapiro and Stiglitz (1984), Akerlof and Yellen (1986), and Krueger and Summers (1988).

The plan of the paper is as follows: In Section 1 we present the model and state and prove our main result. Finally, we offer some concluding remarks.

\section{THE MODEL}

Let us consider a firm which produces a single output using two types of workers. We assume that these workers are economically identical (i.e. workers are perfect substitutes, their supply functions have equal elasticity) and that their only differences are some characteristics that do not influence

6 Although this doesn't yield discrimination. 
in the productive process of the firm. These characteristics may be race, age, sex, or some other publicly observable trait.

The firm is assumed to be competitive in the output market and monopsonist in input markets. In addition, let us suppose that the firm is managed by someone who does not like one of the two kinds of workers. This dislike is expressed by an increase in the manager's effort, which means more input without any additional cost for the firm in order to avoid contact with such a group of workers. In other words, if the firm would hire less workers discriminated by the manager, the latter would be willing to increase his effort to maintain the production level.

The technology of the firm is represented by the production function $f\left(x_{1}, x_{2}, x_{3}, e\right)$ which is assumed to be strictly concave and to depend on the hours worked by both types of workers, and those of the discriminating manager as well as his effort $e\left(x_{1}, w\right)$ depending on the number of type 1 workers and his own wage $w$. Since the manager's wage is given by the firm, for the sake of simplicity we can assume that the effort $e$ depends only on the hours worked $x_{1}$ by type 1 workers.

Let us assume that the supply function for both type 1 and type 2 workers are $X_{1}\left(w_{1}\right)$ and $X_{2}\left(w_{2}\right)$ which have all the properties (e.g. strictly monotone) to guarantee the existence of the inverse functions $W_{1}\left(x_{1}\right)$ and $W_{2}\left(x_{2}\right)$ representing the wages type 1 and 2 workers, respectively.

Therefore, the goal of the firm can be stated in two equivalent ways: one in terms of supply functions:

$$
\underset{w_{1}, w_{2}, x_{1}, x_{2}, x}{\operatorname{Max}} \operatorname{pf}\left(x_{1}, x_{2}, x, e\right)-w_{1} x_{1}-w_{2} x_{2}-w x
$$

subject to

$$
X_{i}\left(w_{i}\right)-x_{i} \leq 0, w_{i}, x_{i}, x \geq 0, i=1,2 .
$$

and the other in terms of inverse supply functions: 


$$
\underset{w_{1}, w_{2}, x_{1}, x_{2}, x}{\operatorname{pax}} p f\left(x_{1}, x_{2}, x, e\right)-w_{1} x_{1}-w_{2} x_{2}-w x
$$

subject to

$$
W_{i}\left(x_{i}\right)-w_{i} \leq 0, w_{i}, x_{i}, x \geq 0, i=1,2 .
$$

Since the two problems above are equivalent, the choice is exclusively for convenience. We choose the latter. Also, notice that constraints are binding (the monopsonist would forgo profits if he hired labor above the wage for which workers would be willing to sell their labor). Therefore, the firm's decision problem can be reduced to the unconstrained program:

$$
\operatorname{Max}_{x_{i} \geq 0, x \geq 0} p f\left(x_{1}, x_{2}, x, e\right)-C\left(x_{1}, x_{2}, x\right)
$$

where $C$ denotes the cost function:

$$
C\left(x_{1}, x_{2}, x\right)=W_{1}\left(x_{1}\right) x_{1}+W_{2}\left(x_{2}\right) x_{2}+w x,
$$

which is assumed to be a strictly convex. For instance, $W_{1}\left(x_{1}\right)$ and $W_{2}\left(x_{2}\right)$ could be $A x_{1}{ }^{\alpha}$ and $B x_{2}{ }^{\beta}$ respectively, with $A \neq B$ and with elasticity $\alpha>1$.

Remark: Before solving the firm's problem, let us discuss the case in which the manager's effort is missing. To put things in a simple way, let us assume conditions that assure an interior solution which will be characterized by:

$$
\begin{aligned}
& p \frac{\partial f}{\partial x_{1}}=W_{1}\left(x_{1}\right)+W^{\prime}{ }_{1}\left(x_{1}\right) x_{1} \\
& p \frac{\partial f}{\partial x_{2}}=W_{2}\left(x_{2}\right)+W^{\prime}{ }_{2}\left(x_{2}\right) x_{2} \\
& p \frac{\partial f}{\partial x}=w
\end{aligned}
$$

As we are interested in the wage differential, we divide equation (2) by equation (3) to obtain: 


$$
1=\frac{W_{1}\left(x_{1}\right)+W_{1}^{\prime}\left(x_{1}\right) x_{1}}{W_{2}\left(x_{2}\right)+W^{\prime}{ }_{2}\left(x_{2}\right) x_{2}}
$$

which, in terms of the elasticities, is equivalent to

$$
\frac{W_{2}\left(x_{2}\right)}{W_{1}\left(x_{1}\right)}=\frac{\left(1+\varepsilon\left(W_{1}\left(x_{1}\right)\right) \varepsilon\left(W_{2}\left(x_{2}\right)\right)\right.}{\left(1+\varepsilon\left(W_{2}\left(x_{2}\right)\right) \varepsilon\left(W_{1}\left(x_{1}\right)\right)\right.}
$$

From (5) it follows that the wage differential is due to the elasticity of the supply functions of the type of workers. However, if we assume, in addition to equal productivity, that both elasticities are equal, there would be no discrimination (the wage would be equal). Now, if we assume that the manager's effort affects the production level and represents no additional cost for the firm, then the discrimination emerges in an endogenous way because of the trade-off between effort and the number of type 1 workers. This tradeoff is represented by the condition $e^{\prime}\left(x_{1}\right)<0$. That is, if the firm decides to hire less workers of type 1 , the manager would be willing to increase his effort to maintain the production level.

Formally our main result is stated in the following theorem

Theorem 1: If the type 1 and 2 workers have the same productivity ${ }^{7}$, and, in addition, both supply functions have the same elasticity, then a sufficient condition for the firm to discriminate type 1 workers is that its manager faces a trade-off between his effort level and the number of workers of type 1 .

Proof: From properties imposed on the production function $f$ and supply functions $X_{1}, X_{2}$, we can conclude that there exists a unique solution that can be found by solving the Kuhn-Tucker conditions:

$$
p\left\{\frac{\partial f}{\partial x_{1}}+\frac{\partial f}{\partial e} e^{\prime}\left(x_{1}\right)\right\} \leq W_{1}\left(x_{1}\right)+W^{\prime}{ }_{1}\left(x_{1}\right) x_{1}
$$

7 In the sense that they are perfect substitutes. 


$$
\begin{aligned}
& p \frac{\partial f}{\partial x_{2}} \leq W_{2}\left(x_{2}\right)+W_{2}^{\prime}\left(x_{2}\right) x_{2}, \\
& x_{1}\left\{p \frac{\partial f}{\partial x_{1}}+\frac{\partial f}{\partial e} e^{\prime}\left(x_{1}\right)-W_{1}\left(x_{1}\right)-W_{1}^{\prime}\left(x_{1}\right) x_{1}\right\}=0 \\
& x_{2}\left\{p \frac{\partial f}{\partial x_{2}}-W_{2}\left(x_{2}\right)-W_{2}^{\prime}\left(x_{2}\right) x_{2}\right\}=0 \\
& x\left\{p \frac{\partial f}{\partial x}-w\right\}=0
\end{aligned}
$$

In principle, we may have a corner solution $\left(x_{1}, x_{2}, x\right)=(0,0,0)$. But if $W_{i}(0)-\frac{\partial C}{\partial x_{i}}(0,0,0)<0, \quad i=1,2$, an interior solution is assured, which is characterized by $(6),(7),(8)$ and $(9)$ with equality.

As remarked above, we divide the equation (7) by equation (8) to obtain:

$$
\left(1+\frac{\frac{\partial f}{\partial f}}{\frac{\partial f}{\partial x_{1}}} e^{\prime}\left(x_{1}\right)\right)=\frac{W_{1}\left(x_{1}\right)+W_{1}^{\prime}\left(x_{1}\right) x_{1}}{W_{2}\left(x_{2}\right)+W_{2}^{\prime}\left(x_{2}\right) x_{2}}
$$

which, in terms of elasticities, is equivalent to

$$
\left(1+\frac{\frac{\partial f}{\partial f}}{\frac{\partial f}{\partial x_{1}}} e^{\prime}\left(x_{1}\right)\right)=\frac{W_{1}\left(x_{1}\right)\left(1+\varepsilon\left(W_{1}\left(x_{1}\right)\right)\right) \varepsilon\left(W_{2}\left(x_{2}\right)\right)}{W_{2}\left(x_{2}\right)\left(1+\varepsilon\left(W_{2}\left(x_{2}\right)\right)\right) \varepsilon\left(W_{1}\left(x_{1}\right)\right)}
$$

But, as we are assuming equal elasticities the right-hand side of the previous equality is reduced to $\frac{W_{1}\left(x_{1}\right)}{W_{2}\left(x_{2}\right)}$ Therefore, one has 


$$
\left(1+\frac{\frac{\partial f}{\partial e}}{\frac{\partial f}{\partial x_{1}}} e^{\prime}\left(x_{1}\right)\right)=\frac{W_{1}\left(x_{1}\right)}{W_{2}\left(x_{2}\right)}
$$

Since the wages are positive, the factor $\left(1+\frac{\frac{\partial f}{\partial e}}{\frac{\partial f}{\partial x_{1}}} e^{\prime}\left(x_{1}\right)\right)$ must be positive as well. But as $e^{\prime}\left(x_{1}\right)<0$, then such a factor must be strictly less than one, so $W_{1}\left(x_{1}\right)<W_{2}\left(x_{2}\right)$. Therefore, there exists economic discrimination and the theorem is completed.

Remarks: If we consider $e^{\prime}\left(x_{1}\right)>0$ instead of $e^{\prime}\left(x_{1}\right)<0$ the conclusion of Theorem 1 would be a wage differential against workers of type 2 . Therefore, it does not matter if he likes or dislikes workers of type 1 for the firm to discriminate. In other terms, it is sufficient to assume $e^{\prime}\left(x_{1}\right) \neq 0$ (in Theorem 1) for the firm to assign different wages.

\section{CONCLUSION}

In this paper we have shown that if a manager of a monopsonistic firm does not like one of two kinds of workers that the firm has available to hire, this fact alone is a sufficient condition for economic discrimination to emerge in an endogenous way in the labor market. To reach this result we had to impose, in addition to having the same productivity, one additional condition: both supply functions should have the same elasticity. This would guarantee wage differentials, and therefore discrimination. Notice that in our model different wages are assigned to equally productive workers who have equal supply elasticities. 
Finally, our result shows that the interaction among workers of a same firm may have bad consequences in terms of production. In this way, our result suggests that firms should design good mechanisms to improve relationships among their employees, and thus eliminate discrimination.

\section{REFERENCES}

AKERLOF, G. A.; YELLEN, J. L. Introduction. In: Efficiency wage models of the labor markets. Cambridge: Cambridge University Press, 1986, p. 1-21.

ARROW, Kenneth. The theory of the discrimination. In: ASHENFELTER, O. A.; REES, A. (eds.), Discrimination in labor markets. Princeton, N. J.: Princeton University Press, 1973, p. 3-33.

BECKER, G. S. The economics of discrimination. Second Edition. University of Chicago Press, 1971.

BLACK, Dan A. Discrimination in an equilibrium search model'. Joumal of Labor Economics, v. 13, n. 2, p. 309-334, 1995.

FARIA, J. R. The economics of witchcraft and the big eye effect. Kyklos, v. 51, fasc.4, p. 537-546, 1998.

. Supervision and effort in an intertemporal efficiency wage model: The role of the Solow condition. Economics Letters, 67, p. 93-98, 2000.

FRIJTERS, P. Discrimination and job uncertainty. Journal of Economic Behaviour and Organization, 36, p. 433-446, 1998.

KRUEGER, Alan B.; SUMMERS, Lawrence H. Efficiency wages and the inter-industry wage structure. Econometrica, v. 56, n. 2, p. 259293, March 1988.

PHELPS, Edmund S. The statistical theory of racism and sexism. American Economic Review, 62, p. 659-661, 1972.

SHAPIRO, Carl; STIGLITZ, Joshep E. Equilibrium unemployment as a worker discipline device. American Economic Review, v. 74, n. 3, p. 433-44, June 1984.

SOLOW, R. M. Another possible source of wage stickness. Journal of Macroeconomics, 1, p. 79-82, 1979.

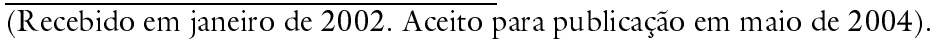

